\title{
BIM and IoT for the AEC Industry: A systematic literature mapping
}

\author{
Beatriz Campos Fialho \\ The University of Sao Paulo | Brazil | beatriz.fialho@usp.br \\ Ricardo Codinhoto \\ The University of Bath | United Kingdom | rc784@bath.ac.uk \\ Márcio Minto Fabricio \\ The University of Sao Paulo | Brazil | marcio.m.fabricio@usp.br
}

\begin{abstract}
The AEC industry has been facing a digital transformation for improving services involved in buildings lifecycle, fostered by two disruptive technologies: Building Information Modelling (BIM) and Internet of Things (IoT). However, the literature lacks discussions regarding applications and challenges of BIM and loT systems in the AEC. This Systematic Literature Mapping addresses this gap through search, analysis, and classification of 75 journal article abstracts published between 2015 and 2019. An increase of articles over the period is observed, predominantly with technical and processual solutions for Construction and Operation and Maintenance. The interoperability of data is a key challenge to organizations.
\end{abstract}

Keywords: Building Information Modelling; Internet of Things; Integration; Network; Smart Cities

\section{INTRODUCTION}

The Architecture and Engineering Construction (AEC) industry has been facing a digital transformation for improving the efficiency of services involved in designing, building and operating assets, and the users' well-being in the built environment and urban spaces. Such a transformation towards sustainable smart cities has been fostered by two disruptive Information and Communication Technologies (ICTs), namely Building Information Modelling (BIM) and Internet of Things (IOT).

Defined as "the 'current expression of digital innovation' across the construction industry" (BIMe Initiative, 2016), BIM integrates the information of a building and its objects in a centralized digital database. It enables the collaboration among stakeholders through the building life cycle (Eastman, Teicholz, Sacks, \& Liston, 2014) and changes in the design process development and management (Emmitt, 2016), thus increasing the accuracy and availability of information and the final building quality.

Based on a network that connects physical objects to the Internet (Madakan, Ramaswamy, \& Tripathi, 2015), loT is also considered a key component of the smart cities concept, since it converges "physical, digital and human systems in the built environment to deliver a sustainable, prosperous and inclusive future for its citizens" (BSI, 2014, p. 3). IoT enables a real-time understanding of every aspect and component of a building and its operation, increasing the accuracy and availability of information (Gunduz, Isikdag, \& Basaraner, 2017; Pishdad-Bozorgi, 2017; Wong, Ge, \& He, 2018). Moreover, loT supports constructors and managers to overcome one of BIM limitations, i.e. the static building information, raising the efficiency of services to a higher level.

Although a variety of technological solutions have been recently developed, understanding their benefits for the AEC activities is still a challenge, in special for the Facilities Management (FM) sector (Codinhoto, Fialho, Pinti, \&
Fabricio, 2020). BIM and loT-based systems offer the opportunity to automatize processes and support changes in the industry from a reactive to a predictive approach. The novelty and importance of the field justify the development of academic and technical investigations.

Previous studies have focused on the identification of BIM and loT technologies applicable to FM industry processes, describing suitable devices, tools and software for data collection, storage and sharing (Fialho, Codinhoto, \& Fabricio, 2019; Ye, Yin, Tang, \& Jiang, 2018), as well as fields of application of their combined solutions (e.g. Construction, Operations and Maintenance) (Kensek \& Kahn, 2013; Pärn \& Edwards, 2017; Ramprasad et al., 2018; Vandecasteele, Merci, \& Verstockt, 2017). Nevertheless, the literature still lacks discussions regarding the broad implementation BIM and loT-based systems in the AEC industry. This study focuses on the establishment of contextual knowledge concerning the applications and challenges of BIM and IOT systems integration through search, analysis, and classification of journal article abstracts published between 2015 and 2019 .

\section{MATERIAL AND METHODS}

A Systematic Literature Mapping (SLM) was conducted to develop a broad perspective of the subject and a structured classification of publications, supporting future studies (Gough, Oliver, \& Thomas, 2012; Petersen, Feldt, Mujtaba, \& Mattsson, 2008). A research protocol synthesized the structure and criteria for the work (Table 1).

The Science Direct (Elsevier) database was considered appropriate for this study, providing relevant publications on the topic. Keywords and Boolean operators were defined for addressing both individual BIM and IoT concepts and the context for BIM and loT integration. Filters for selecting innovative works include peer-reviewed journal articles published in Portuguese and English from 2015 to 2019. The five-year term was defined due to the 
constant evolution of the area, in which technological solutions rapidly become obsolete. From 146 identified entries, 75 abstracts were chosen for further analysis after applying the filters and selection criteria.

Table 1: Research protocol.

\begin{tabular}{ll}
\hline Item & Content \\
\hline Research & What are the applications and challenges of \\
questions & BIM and loT systems integration in the AEC \\
Key & industry? \\
objectives & To develop contextual knowledge concerning \\
& the applications and challenges of BIM and \\
& IOT systems integration through search, \\
& analysis, and classification of journal article \\
Database & Science Direct (Elsevier) \\
Keywords & ("building information modelling" OR "building \\
& information modeling" OR "bim") and ("IOT" \\
& OR "loT system" OR "loT platform") AND \\
& ("integration" OR "connection") AND \\
& ("Computer Networks and Communications" \\
Filters & OR "network") AND "Smart cities" \\
& Year of publication: 2015 to 2019. Type of \\
& publication: peer-reviewed journal articles. \\
Language: English and Portuguese \\
criteria & Inclusion criteria: articles on BIM and IOT \\
& systems. \\
& Exclusion criteria: Publications neither \\
& correlated to BIM and loT systems, nor \\
& written in the aforementioned languages. \\
\hline
\end{tabular}

\section{RESEARCH FINDINGS}

\section{BIBLIOMETRIC ANALYSIS}

Table 2 shows the distribution of articles published in Journals over time. An increase in submissions over the five past years is verified, particularly in 2018 (21) and 2019 (35). Automation in Construction concentrates $38 \%$ of the articles (29), followed by Advanced Engineering Informatics (6), Procedia Engineering account (6), and the Journal of Cleaner Production (5).

The distribution of authors country per article is illustrated in Figure 1. The authors are predominantly from the UK, USA, and China. $30 \%$ of the total number of publications comprehend more than one country, evidencing the partnership among nations. Together, Europe and Asia concentrate $80 \%$ of the whole publications. South America accounts for only one article, which demonstrates research opportunities on the topic in the region.

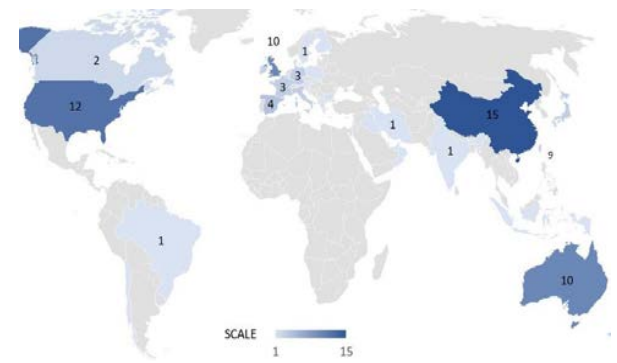

Figure 1: Distribution of authors country per article.

The distribution of articles per overall research method is shown in Figure 2. Literature Review was adopted in 24 articles, followed by Case Study (19) and Experimental methods (14). Other methods include Interviews and questionnaires (4), Simulation (2), and Axiomatic design (1). The methods applied were not clearly identified in 11 articles, and, in most cases, the aim was to demonstrate the application of BIM- and loT-based solutions in AEC processes and activities.

Table 2: Distribution of articles published in Journals per year.

\begin{tabular}{|c|c|c|c|c|c|c|}
\hline Journal & $\stackrel{n}{\circ}$ & $\stackrel{\infty}{i}$ & $\frac{N}{\delta}$ & $\stackrel{\infty}{\circ}$ & $\stackrel{\circ}{\circ}$ & $\stackrel{0}{3}$ \\
\hline $\begin{array}{l}\text { Automation in } \\
\text { Construction }\end{array}$ & 1 & 1 & 3 & 10 & 14 & 29 \\
\hline $\begin{array}{l}\text { Advanced Engineering } \\
\text { Informatics }\end{array}$ & & 1 & & 1 & 4 & 6 \\
\hline Procedia Engineering & 2 & & 4 & & & 6 \\
\hline $\begin{array}{l}\text { Journal of Cleaner } \\
\text { Production }\end{array}$ & & 1 & 1 & 1 & 2 & 5 \\
\hline $\begin{array}{l}\text { Procedia Computer } \\
\text { Science }\end{array}$ & & & & 2 & 2 & 4 \\
\hline $\begin{array}{l}\text { Future Generation } \\
\text { Computer Systems }\end{array}$ & & & & 1 & 2 & 3 \\
\hline Computers in Industry & & & & 1 & 1 & 2 \\
\hline $\begin{array}{l}\text { Journal of Building } \\
\text { Engineering }\end{array}$ & & & & & 2 & 2 \\
\hline Procedia Manufacturing & & & 1 & 1 & & 2 \\
\hline $\begin{array}{l}\text { Sustainable Cities and } \\
\text { Society }\end{array}$ & & & & 2 & & 2 \\
\hline $\begin{array}{l}\text { Technological Forecasting } \\
\text { and Social Change }\end{array}$ & & & & 2 & & 2 \\
\hline Building and Environment & & & & & 1 & 1 \\
\hline Cities & & & & & 1 & 1 \\
\hline Computer Networks & & & & & 1 & 1 \\
\hline $\begin{array}{l}\text { Computers \& Industrial } \\
\text { Engineering }\end{array}$ & & & & & 1 & 1 \\
\hline Energy Procedia & & & & & 1 & 1 \\
\hline Habitat International & & 1 & & & & 1 \\
\hline IFAC-PapersOnLine & 1 & & & & & 1 \\
\hline $\begin{array}{l}\text { Journal of Urban } \\
\text { Management }\end{array}$ & & & & & 1 & 1 \\
\hline Neurocomputing & & & & & 1 & 1 \\
\hline Renewable and & & & 1 & & & 1 \\
\hline $\begin{array}{l}\text { Sustainable Energy } \\
\text { Reviews }\end{array}$ & & & & & & \\
\hline $\begin{array}{l}\text { Resources, Conservation } \\
\text { and Recycling }\end{array}$ & & & 1 & & & 1 \\
\hline Safety Science & & & & & 1 & 1 \\
\hline Total & 4 & 4 & 11 & 21 & 35 & 75 \\
\hline
\end{tabular}

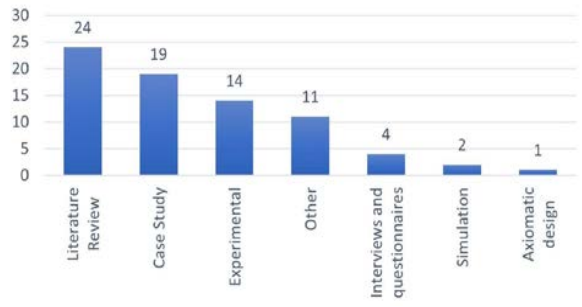

Figure 2: Distribution of articles per overall research method.

The distribution of articles per research focus on the AEC stages is shown in Figure 3. Construction and Operation \& Maintenance (O\&M) stages are the focus of 44 articles. 24 publications discuss BIM and loT integration in a broad view and with no relation to specific AEC stages. Manufacturing is described in 4 articles, regarding building components production, while Design, Renovation, and Demolition are addressed in 3 articles. 


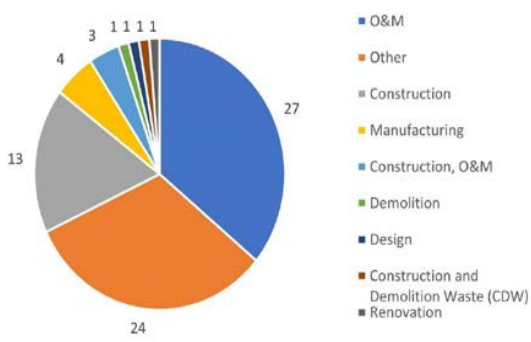

Figure 3: Distribution of articles per research focus on the AEC stages.

Table 4 presents the distribution of articles per year according to the research focus on three categories, namely 1 . Theory, which includes Literature Review and conceptual propositions; 2. Information Technology (IT), related to the development of interfaces, platforms, systems, and ontologies for BIM and loT integration; and 3. Process, regarding approaches, frameworks, methods, and models for BIM and loT integration. Focus on Process was identified in most publications (29), followed by IT, in 24, and Theory, in 22 articles.

Table 4: Distribution of articles per year according to the research focus - Theory, IT and Process.

\begin{tabular}{|c|c|c|c|c|c|c|}
\hline Research Focus and Example & $\stackrel{10}{\stackrel{2}{2}}$ & $\frac{0}{2}$ & $\hat{\bar{N}}$ & $\sum_{\text {D }}^{\infty}$ & $\stackrel{\text { D) }}{\frac{N}{N}}$ & $\begin{array}{l}\stackrel{0}{丂} \\
\text { की }\end{array}$ \\
\hline $\begin{array}{l}\text { Theory: "A concept for securing } \\
\text { distributed applications and } \\
\text { services in data infrastructures for } \\
\text { Smart Cities" (CHATURVEDI et al., } \\
\text { 2019) }\end{array}$ & 1 & 0 & 4 & 4 & 13 & 22 \\
\hline $\begin{array}{lll}\text { Information Technology } & \text { (IT): } \\
\text { "Internet of Things-enabled } & \text { BIM } \\
\text { platform (IBIMP) for the Modular } \\
\text { Integrated Construction } & \text { (MiC) } \\
\text { project" (ZHAI et al., 2019) } & \end{array}$ & 1 & 2 & 6 & 7 & 8 & 24 \\
\hline $\begin{array}{l}\text { Process: "Smart Sewer Asset } \\
\text { Information Model (SSAIM) for an } \\
\text { existing sewerage network" } \\
\text { (ZHONG et al., 2015) }\end{array}$ & 2 & 2 & 1 & 10 & 14 & 29 \\
\hline Total & 4 & 4 & 11 & 21 & 35 & 75 \\
\hline
\end{tabular}

\section{ABSTRACT ANALYSIS}

The 75 selected abstracts were analysed for the identification of propositions for BIM and loT integration and challenges and problems faced on this procedure. To do so, the articles were grouped according to the research focus (i.e. Theory, Process, and IT), emphasizing common scopes of the categories.

In the Theory group, 20 literature review articles discuss the role of emerging ICTs in AEC industry digital transformation. Tang et al. (2019) identified the application of BIM tools' APIs and semantic web technologies to the Construction and O\&M. Wong, Ge and He (2018) explored digital technological developments into FM, including BIM and loT. IoT has been explored as a disruptive technology in distinct perspectives, i.e. fostering the development of business models in Smart Cities scenario (Alcayaga, Wiener, \& Hansen, 2019); supporting the evolution of AEC (Woodhead, Stephenson, \& Morrey, 2018) and the smart building industry (Magruk, 2015), specifically over construction and O\&M (Jia, Komeily, Wang, \& Srinivasan, 2019); contributing to the remanufacturing sector in combination with Virtual Reality (VR) and Augmented Reality (AR) (Kerin \& Pham, 2019); and supporting intrusion detection in computer networks (Kelton, Papa, Lisboa, Munoz, \& De, 2019). Improvements in the integration of concepts for supporting performance economy and between cyber-physical systems (CPS) and IoT are described as important challenges. IoT supports the development of new concepts. Chaturvedi et al. (2019) proposed the "Smart District Data Infrastructure (SDDI) concept" integrating sensors, simulation tools, and 3D models of cities. Yan and Sakairi (2019) discussed loT and CPS in the context of urban management, supporting the "Geo CPS" proposed concept.

BIM has been approached as a central concept for the AEC evolution in some reviews. Gao and Pishdad-Bozorgi (2019) and Araszkiewicz (2017) discussed its application in O\&M, highlighting the integration of building lifecycle data and decision-making support as benefits. Energy management is one of the key areas (Araszkiewicz, 2017) fostered by Building Energy Modeling methodologies and BIM database (Pezeshki, Soleimani, \& Darabi, 2019). The use of BIM in urban infrastructure was explored by Costin et al. (2018) and Rice and Martin (2018). Other BIM applications involve off-site construction (OSC) (Yin, Liu, Chen, \& Al-hussein, 2019), network security and data management (Nawari \& Ravindran, 2019), and data integration, building energy management and urban governance (Wang, Pan, \& Luo, 2019), promoted by BIM, GIS and complementary technologies (Ma \& Ren, 2017; Pauwels, Zhang, \& Lee, 2017).

With regards to the Information Technology (IT) group, some articles address the development of platforms, systems, interfaces and ontologies integrating BIM and loT for various purposes in the built environment. Dave et al. (2018) proposed the Otaniemi3D web-based platform, associating BIM models with built environment data from IoT sensors. Lokshina, Greguš and Thomas (2019) developed a system design for improvements in data security, exchange, and sharing among stakeholders.

Prefabricated construction is the focus of some studies. Zhai et al. (2019) has developed an "Internet of Thingsenabled BIM platform (IBIMP) for Modular Integrated Construction (MiC) project" to support data collection and automatic decision support. Zhengdao et al. (2016b) generate an loT-enabled platform to streamline offshore prefabricated construction processes, while Zhengdao et al. (2017) develop a "RFID-enabled BIM platform" to manage critical schedule factors. Zhengdao et al. (2018) design an loT-enabled platform by integrating BIM, RFID and VR technologies for facilitating the on-site assembly services (OAS) and Zhong et al. (2017) propose a "Multidimensional Internet of Things (IoT)-enabled BIM platform (MITBIMP)" for real-time traceability and visibility of components. The potential benefits of the presented solutions include availability of real-time cost information, remote supervision of construction progress, and information sharing among participants. BIM- and IoTbased solutions have also been proposed for O\&M, i.e. a system to recognize unsafe worker behaviours in building environments (Arslan, Cruz, \& Ginhac, 2019b); a "BIMbased visualization and warning system for fire rescue" (Chen, Liu, \& Wu, 2018); a "semantic knowledge management service and domain ontology" combining BIM and smart water field systems for improvements in systems 
performance (Howell, Rezgui, \& Beach, 2017), and the Real-Time Replay System (RTRS) for building' users managing energy consumption and conservation (Chiang, Chu, \& Chou, 2015).

The development of loT-based platforms for distinct lifecycle stages is the scope of some articles. In construction, a virtual experimental platform was proposed for simulating the use of an loT-enabled control for an earthmoving work (Louis \& Dunston, 2018), as well as a cloud-based loT platform for managing physical assets (G. $\mathrm{Xu}, \mathrm{Li}, \mathrm{Chen}, \&$ Wei, 2018), and an "IoT-enabled Smart Factory Visibility and Traceability Platform" for smart factory production (Zhong, Xu, \& Wang, 2017). The propositions for O\&M include the "IoT Energy Platform (loTEP)" for management, processing, and analysis of building energy data (Terroso-saenz, González-vidal, Ramallo-gonzález, \& Skarmeta, 2019); a sensor management system for energy efficiency of smart buildings (Plageras, Psannis, Stergiou, Wang, \& Gupta, 2018); and an integration citizen's suggestion system for user's communication (Ham, Teng, Wijaya, \& Wikopratama, 2018). Addressing Health and Safety, a framework for information integration and a prototype system for safety monitoring over the AEC industry were introduced (Q. Xu, Chong, \& Liao, 2019), as well as a "cyber-physical-system-based safety monitoring system" for hoisting in underground constructions (Zhou, Luo, Fang, Wei, \& Ding, 2019).

BIM-based systems and interfaces were proposed for distinct applications, i.e. a BIM-based interface to support customers in exploring design solutions in masscustomized housing sector (Bianconi, Filippucci, \& Buffi, 2019); a BIM-based prototype CPS for structural health monitoring (SHM) (Fitz, Theiler, \& Smarsly, 2019); a GISBIM based system for urban energy planning optimization (Yamamura, Fan, \& Suzuki, 2017); an "interactive Augmented Reality system for Temporal and Spatial analysis of power consumption data integrated with building information models (iARTS)" (Chou, Chiang, Wu, Chu, \& Lin, 2017).

Regarding the Process group, frameworks, approaches, models, and methods for the integration of BIM and IoT have aimed streamlining AEC processes. Heaton and Parlikad (2019) developed a "smart asset alignment framework" integrating infrastructure asset information and citizen necessities; Love, Matthews and Gates (2019) proposed a generic business dependency network (BDN) for analysis of multiple relationships of digital technologies implementation; and Motamedi et al. (2016) introduced a method for setting RFID technology components in BIM. Focusing on anticipating building users' needs, Ciribini et al. (2017) developed a workflow to populate BIM models with sensors' data. Arslan, Cruz and Ginhac (2019b) designed the "Occupant Behaviors in Dynamic Environments (OBiDE) framework" incorporating the environment information. Zhengdao et al. (2016a) provide a BIM-loT based method that analyses risk factors and effects for stakeholders in prefabrication construction.

O\&M-oriented solutions are addressed by Rashid, Louis and Fiawoyife (2019), who introduced a framework for electrical fixtures control in smart built environments, integrating an ultra-wideband-based indoor positioning system with a BIM-based virtual environment, and
Edmondson et al. (2018), through a "Smart Sewer Asset Information Model (SSAIM)" for managing operations. In the Health and Safety domain, Liu et al. (2019) developed a method for safety inspection integrating BIM and unmanned aerial vehicle (UAV) camera for supplying industrial and residential water, and Peng, Li and $\mathrm{Hu}$ (2019) proposed a neural networks-based approach for evacuation planning in grand public buildings.

IoT-centred solutions are also developed, i.e. a framework for safety management and monitoring in complex environments (Haddad, Bouyahia, \& Chaudhry, 2019); "a big data analytics for loT-enabled manufacturing shop floor" (Kho et al., 2018); "a Physical Internet-enabled decision support system (DSS)" for tracking components and mapping real-time interactions among stakeholders of prefabricated housing construction (Zhong et al., 2015); and a semantic knowledge model for smart buildings using the IndoorGML standard (Rubio et al., 2018).

Difficulties related to BIM embracement by AEC industry have fostered some propositions, i.e. a "Unified BIM Adoption Taxonomy (UBAT)" for classification and integration of drivers and factors for BIM adoption (Louay \& Kassem, 2018); models, matrices and charts for macroBIM adoption assessment and BIM diffusion policies information (Succar \& Kassem, 2015, p. 64); a recommendation for building geometry representation (Mcglinn et al., 2019); and the DALTON (DAta Linked Through Occurrences Network) conceptual model, that provides checking components for business rules (Fortineau, Paviot, \& Lamouri, 2019).

BIM-based solutions have been proposed for construction and demolition stages. Among such solutions are the "smart work packaging (SWP)" for constraints management (X. Li, Qiping, et al., 2019) and the conceptual framework for BIM integration in prefabrication housing production (X. Li, Wu, \& Yue, 2019); a group of BIM expectations for construction and demolition waste management (Akinade et al., 2018); a conceptual "Reverse logistics supply chain (RLSC)" model to support demolition and reprocessing of salvaged materials (Chileshe, Jayasinghe, \& Rameezdeen, 2019). Processual solutions have also been proposed for O\&M, i.e. a "Diagnosis-Aided Historic Building Information Modelling and Management framework" (Bruno, Fino, \& Fatiguso, 2018), an "Integrated Knowledge-based Building Management System" for detecting and diagnosing operational faults (Gha et al., 2019), and "an object-oriented city design model" for building energy performance assessment (Zachary et al., 2019).

Additional approaches and technologies were addressed, i.e. Good, Ellis and Mancarella (2017) discussed barriers and enablers involved in the demand response of electric systems, Novais, Manuel and Ortiz-Bas (2019) investigated the integration between Cloud Computing and Supply Chain, (J. Li, Greenwood, \& Kassem, 2019) and Marsal-Llacuna (2018) proposed Blockchain-based frameworks supporting the built environment and construction sector, David, Aubry and Derigent (2018) and Yang et al. (2018) introduced integrated frameworks for multisector infrastructure asset management, whereas $\mathrm{Hu}$ et al. (2016) developed a "Resource Description Framework (RDF) syntax structure" for representing existing database information. 


\section{DISCUSSION AND CONCLUSIONS}

This systematic literature mapping analyzed relevant abstract articles published in the past five years. Publications on ICT implementation (i.e. BIM and IoT) in the AEC industry has significantly increased over the period, from 4 in 2015 to 35 in 2019, evidencing an expansion of investigations on the topic, particularly in Europe and Asia (Figure 1). The collaboration among several countries was identified, which enables the research development through distinct approaches.

The predominance of journals in construction and engineering domains (Table 2) demonstrates the applicative bias of the studies, concerned with the AEC demands. Most publications are driven to Construction and O\&M, which evidences the potential advantages of BIM and loT integration for building and managing assets. Regarding the research method (Figure 2), most articles have adopted literature reviews, still required to state a knowledge field, followed by Case Study and experimental methods, demonstrating an orientation to the development of technical and processual solutions for building lifecycle.

Table 4 shows a predominance of articles regarding IT propositions $(47 \%)$ in the first three years (2015-2017) in comparison to theoretical and processual approaches. Mostly, the IT solutions address BIM models and IOT devices integration issues for key areas, i.e. prefabrication construction, building and infrastructure operation and maintenance, energy management, and health and safety. However, this scenario was altered in 2018 and 2019, with a significant increase on processes improvement solutions $(42 \%)$, evidencing the required transformations imposed by BIM and IOT to organizations for adapting traditional activities to a digital environment, thus setting a trend for investigations.

Challenges and problems faced in the BIM and IoT integration are described by few articles (Aguiar et al., 2017; Gao \& Pishdad-bozorgi, 2019; Tang et al., 2019; Wong et al., 2018) in a broad perspective of ICT implementation and can be summarized in one main issue, i.e. interoperability throughout information exchange standards over the building lifecycle. Defined as the "ability of diverse systems (and organizations) to work together seamlessly without data loss and without a special effort" (BIMe Initiative, 2019), the interoperability among AEC processes and systems is crucial for improving the integration among ICT's. Although BIM platforms and IoT devices have individually achieved a high level of development, the generation of effective integrated systems driven to practical problems is required. Governments, professional bodies, and universities around the world has been addressing this gap (Pezeshki et al., 2019) through the definition of mandates, handbooks, and technical standards. Once again, a global effort is needed to stablish a common approach for organizations managing BIM and loT-based systems.

The novelty of the subject and the overall predominance of processes propositions might explain the scarcity of challenge and problems description, commonly identified in practical applications of BIM- and loT-based systems. Besides, articles usually tend to prioritize positive aspects of the research rather than the negative ones. This is more evident in the abstracts of AEC area, that draw in a few words a synthesis of the research structure and results lacking, in some cases, important information on problems and challenges.

In fact, the potential of BIM and loT-based systems for the evolution of AEC service provision is unlimited and still few explored. Understanding the real problems faced by organizations is imperative for the efficacy of BIM and IoT implementation. Opportunities for improvements in the FM sector are described by (Codinhoto et al., 2020), through the analysis of approximately 80.000 work requests of two educational organization in Italy and the UK. Previous results show the relationship between the severity and recurrence of problems as an important metric for identifying critical problems in building facilities. In this sense, the characterization of problems in each context through empirical data is essential to define the most appropriate BIM and loT solutions for specific processes, supporting the implementation of a predictive strategy for problems solving.

Given the embryonic phase of BIM and loT combined areas in the AEC industry, the authors have been working on developing a baseline through theoretical and practical investigations. This study contributes to knowledge by mapping and discussing relevant articles through a systematic method, providing a reference for future literature reviews. In addition, the study stablishes a contextual knowledge from the past five years, identifying the proposed solutions, scenarios of development (i.e. country, lifecycle stage, research method) and trends on the topic advancement.

Some limitations and opportunities were identified in this study. Difficulties were found in tracking publications from a multidisciplinary subject within the database. The selection of keywords and filters was repeatedly tested to get entries addressing the study questions and key objectives. Also, the assessment of abstract articles as a methodological approach has limited deepening the critical analysis. In this respect, a full-text reading is recommended. Finally, empirical investigations are recommended aiming to explore opportunities and strategies for BIM and loT-based systems implementation as disruptive solutions for AEC industry.

\section{ACKNOWLEDGMENTS}

The authors would like to acknowledge the Brazilian financial support by Coordenação de Aperfeiçoamento de Pessoal de Nivel Superior (CAPES) Grant No. 88881.188668/2018-01, São Paulo Research Foundation (FAPESP) Grant No. 2019/05640-4, and National Council for Scientific and Technological Development (CNPQ) Grant No. 306998/2018-1.

\section{REFERENCES}

Aguiar, A., Mira, P., Antunes, A., Cabral, I., Chen, X., Liu, C., ... Beach, T. (2017). Tracking Users' Behaviors through Realtime Information in BIMs: Workflow for Interconnection in the Brescia Smart Campus Demonstrator. Procedia Engineering, 180(March), 1484-1494. Retrieved from https://doi.org/10.1016/j.proeng.2017.04.311

Akinade, O. O., Oyedele, L. O., Ajayi, S. O., Bilal, M., Alaka, A. Owolabi, H. A., \& Arawomo, O. O. (2018). Designing out construction waste using BIM technology: Stakeholders expectations for industry deployment. Journal of Cleaner 
Production, 180, 375-385. Retrieved from https://doi.org/10.1016/j.jclepro.2018.01.022

Alcayaga, A., Wiener, M., \& Hansen, E. G. (2019). Towards a framework of smart-circular systems: An integrative literature review. Journal of Cleaner Production, 221, 622-634. Retrieved from https://doi.org/10.1016/j.jclepro.2019.02.085

Araszkiewicz, K. (2017). Digital Technologies in Facility Management - The state of Practice and Research Challenges. Procedia Engineering, 196(June), 1034-1042. Retrieved from https://doi.org/10.1016/j.proeng.2017.08.059

Arslan, M., Cruz, C., \& Ginhac, D. (2019a). Understanding Occupant Behaviors in Dynamic Environments using OBiDE framework. Building and Environment, 166(May), 106412. Retrieved

https://doi.org/10.1016/j.buildenv.2019.106412

Arslan, M., Cruz, C., \& Ginhac, D. (2019b). Visualizing intrusions in dynamic building environments for worker safety. Safety Science, 120(July), 428-446. Retrieved from https://doi.org/10.1016/j.ssci.2019.07.020

Bianconi, F., Filippucci, M., \& Buffi, A. (2019). Automated design and modeling for mass-customized housing . A web-based design space catalog for timber structures. Automation in Construction, 103(March), 13-25. Retrieved from https://doi.org/10.1016/j.autcon.2019.03.002

BIMe Initiative. (2016). Building Information Modelling (BIM). Retrieved $14 \quad$ May 2019, from https://bimdictionary.com/en/building-information-modelling/1/

BIMe Initiative. (2019). BIM Dictionary - Interoperability, 2019. Retrieved from https://bimdictionary.com/en/interoperability/1

Bruno, S., Fino, M. De, \& Fatiguso, F. (2018). Historic Building Information Modelling: performance assessment for diagnosis-aided information modelling and management. Automation in Construction, 86(December), 256-276. Retrieved from https://doi.org/10.1016/j.autcon.2017.11.009

Chaturvedi, K., Matheus, A., Nguyen, S. H., \& Kolbe, T. H. (2019). Securing Spatial Data Infrastructures for Distributed Smart City applications and services. Future Generation Computer Systems, 101, 723-736. Retrieved from https://doi.org/10.1016/j.future.2019.07.002

Chen, X., Liu, C., \& Wu, I. (2018). A BIM-based visualization and warning system for fire rescue. Advanced Engineering Informatics, 37(April), 42-53. Retrieved from https://doi.org/10.1016/j.aei.2018.04.015

Chiang, C., Chu, C., \& Chou, C. (2015). BIM-enabled power consumption data management platform for rendering and analysis of energy usage patterns. Procedia Engineering, 118, 554-562. Retrieved https://doi.org/10.1016/j.proeng.2015.08.480

Chileshe, N., Jayasinghe, R. S., \& Rameezdeen, R. (2019). Information flow-centric approach for reverse logistics supply chains. Automation in Construction, 106(June), 102858. Retrieved from https://doi.org/10.1016/j.autcon.2019.102858

Chou, C., Chiang, C., Wu, P., Chu, C., \& Lin, C. (2017). Spatiotemporal analysis and visualization of power consumption data integrated with building information models for energy savings. 'Resources, Conservation \& Recycling', 123, 219-229. Retrieved from https://doi.org/10.1016/j.resconrec.2016.03.008

Ciribini, A. L. C., Pasini, D., Tagliabue, L. C., Manfren, M., Daniotti, B., Rinaldi, S., \& De Angelis, E. (2017). Tracking Users' Behaviors through Real-time Information in BIMs: Workflow for Interconnection in the Brescia Smart Campus Demonstrator. Procedia Engineering, 180, 1484-1494. Retrieved from https://doi.org/10.1016/j.proeng.2017.04.311

Codinhoto, R., Fialho, B. C., Pinti, L., \& Fabricio, M. M. (2020). BIM and loT for Facilities Management: Understanding key maintenance issues. In Driving Transformational Change in the Digital Built Environment. Manuscript submitted for publication.
Costin, A., Adibfar, A., Hu, H., \& Chen, S. S. (2018). Building Information Modeling (BIM) for transportation infrastructure Literature review, applications, challenges, and recommendations. Automation in Construction, 94(July), 257281. Retrieved https://doi.org/10.1016/j.autcon.2018.07.001

Dave, B., Buda, A., Nurminen, A., \& Främling, K. (2018). A framework for integrating BIM and loT through open standards. Automation in Construction, 95(August), 35-45. Retrieved from https://doi.org/10.1016/j.autcon.2018.07.022

David, M., Aubry, A., \& Derigent, W. (2018). Towards energy efficient buildings: how ICTs can convert advances? IFACPapersOnLine, 51(11), 758-763. Retrieved from https://doi.org/10.1016/j.ifacol.2018.08.410

Eastman, c., Teicholz, p., Sacks, r., \& Liston, k. (2014). Manual de BIM: um guia de modelagem da informação da construção para arquitetos, engenheiros, gerentes, construtores e incorporadores. Porto Alegre: Bookman.

Edmondson, V., Cerny, M., Lim, M., Gledson, B., Lockley, S., \& Woodward, J. (2018). A smart sewer asset information model to enable an 'Internet of Things' for operational wastewater management. Automation in Construction, 91, 193-205. Retrieved from https://doi.org/10.1016/j.autcon.2018.03.003

Emmitt, S. (2016). BIM and the Future of Design Management. In J. Eynon (Ed.), Construction Manager's BIM Handbook (1st ed., p. 227). Chichester: John Wiley \& Sons Ltd.

Fialho, B. C., Codinhoto, R., \& Fabricio. (2019). Trends in BIM and loT for Reactive Maintenance. In Proceeding of the 36th CIB W78 2019 Conference (pp. 912-925). Newsastle.

Fitz, T., Theiler, M., \& Smarsly, K. (2019). A metamodel for cyberphysical systems. Advanced Engineering Informatics, 41(May), $\quad 100930 . \quad$ Retrieved from https://doi.org/10.1016/j.aei.2019.100930

Fortineau, V., Paviot, T., \& Lamouri, S. (2019). Automated business rules and requirements to enrich product-centric information. Computers in Industry, 104, 22-33. Retrieved from https://doi.org/10.1016/j.compind.2018.10.001

Gao, X., \& Pishdad-bozorgi, P. (2019). BIM-enabled facilities operation and maintenance: A review. Advanced Engineering Informatics, 39(November), 227-247. Retrieved from https://doi.org/10.1016/j.aei.2019.01.005

Gha, A., Zhang, T., Naismith, N., Gha, A., Doan, D. T., Rehman, A. U., ... Tookey, J. (2019). ND BIM-integrated knowledgebased building management: Inspecting post- construction energy efficiency. Automation in Construction, 97(March), 1328. https://doi.org/10.1016/j.autcon.2018.10.003

Good, N., Ellis, K. A., \& Mancarella, P. (2017). Review and classification of barriers and enablers of demand response in the smart grid. Renewable and Sustainable Energy Reviews, 72(January), 57-72. $\quad$ Retrieved from https://doi.org/10.1016/j.rser.2017.01.043

Gough, D., Oliver, S., \& Thomas, J. (2012). Systematic Reviews (1st ed.). London: SAGE.

Gunduz, M., Isikdag, U., \& Basaraner, M. (2017). Integration of BIM, web maps and loT for supporting comfort analysis. In ISPRS Annals of the Photogrammetry, Remote Sensing and Spatial Information Sciences (Vol. 4, pp. 221-227). Retrieved from https://doi.org/10.5194/isprs-annals-IV-4-W4-221-2017

Haddad, H., Bouyahia, Z., \& Chaudhry, S. A. (2019). A Multiagent Geosimulation and IoT-based Framework for Safety Monitoring in Complex Dynamic Spatial Environments. Procedia Computer Science, 151(2018), 527-534. Retrieved from https://doi.org/10.1016/j.procs.2019.04.071

Ham, H., Teng, M. A., Wijaya, E., \& Wikopratama, R. A. (2018). Integration Citizen' Suggestion System for the Urban Development: Tangerang City Case. Procedia Computer Science, 135, 570-578. Retrieved from https://doi.org/10.1016/j.procs.2018.08.210 
Heaton, J., \& Parlikad, A. K. (2019). A conceptual framework for the alignment of infrastructure assets to citizen requirements within a Smart Cities framework. Cities, 90(April), 32-41. Retrieved from https://doi.org/10.1016/j.cities.2019.01.041

Howell, S., Rezgui, Y., \& Beach, T. (2017). Integrating building and urban semantics to empower smart water solutions. Automation in Construction, 81, 434-448. Retrieved from https://doi.org/10.1016/j.autcon.2017.02.004

Hu, S., Corry, E., Curry, E., Turner, W. J. N., \& Donnell, J. O (2016). Building performance optimisation: A hybrid architecture for the integration of contextual information and time-series data. Automation in Construction, 70, 51-61. Retrieved from https://doi.org/10.1016/j.autcon.2016.05.018

Jia, M., Komeily, A., Wang, Y., \& Srinivasan, R. S. (2019). Adopting Internet of Things for the development of smart buildings: A review of enabling technologies and applications. Automation in Construction, 101, 111-126. Retrieved from https://doi.org/10.1016/j.autcon.2019.01.023

Kelton, A. P., Papa, J. P., Lisboa, C. O., Munoz, R., \& De, V. H. C (2019). Internet of Things: A survey on machine learningbased intrusion detection approaches. Computer Networks 151, 147-157 from https://doi.org/10.1016/j.comnet.2019.01.023

Kensek, K., \& Kahn, W. (2013). Integration of Environmenta Sensors with BIM Seven Case Studies. In BESS--SB13 CALIFORNIA: Advancing Towards Net Zero (pp. 29-35) Pomona.

Kerin, M., \& Pham, D. T. (2019). A review of emerging industry 4.0 technologies in remanufacturing. Journal of Cleaner Production 237. 117805. Retrieved from https://doi.org/10.1016/j.jclepro.2019.117805

Kho, D. D., Lee, S., Zhong, R. Y., Kho, D. D., Lee, S., Zhong, R Y., ... Wernke, R. (2018). Big Data Analytics for Processing Time Analysis in an loT-enabled manufacturing Shop Floor. Procedia Manufacturing, 26, 1411-1420. Retrieved from https://doi.org/10.1016/j.promfg.2018.07.107

Li, J., Greenwood, D., \& Kassem, M. (2019). Blockchain in the built environment and construction industry: A systematic review, conceptual models and practical use cases. Automation in Construction, 102(March), 288-307. Retrieved from https://doi.org/10.1016/j.autcon.2019.02.005

Li, X., Qiping, G., Wu, P., Xue, F., Chi, H., \& Zhengdao, C. (2019). Developing a conceptual framework of smart work packaging for constraints management in prefabrication housing production. Advanced Engineering Informatics, 42(June), 100938. Retrieved from https://doi.org/10.1016/j.aei.2019.100938

Li, X., Wu, P., \& Yue, T. (2019). Integrating Building Information Modeling and Prefabrication Housing Production. Automation in Construction, 100(January 2018), 46-60. Retrieved from https://doi.org/10.1016/j.autcon.2018.12.024

Liu, D., Chen, J., Hu, D., \& Zhang, Z. (2019). Dynamic BIMaugmented UAV safety inspection for water diversion project. Computers in Industry, 108, 163-177. Retrieved from https://doi.org/10.1016/j.compind.2019.03.004

Lokshina, V., Greguš, M., \& Thomas, W. L. (2019). Application of Integrated Building Information Modeling, loT and Blockchain of Technologies in System Design of Smart Building. Procedia Computer Science, 160, 497-502. Retrieved from https://doi.org/10.1016/j.procs.2019.11.058

Louay, A., \& Kassem, M. (2018). A unified BIM adoption taxonomy: Conceptual development , empirical validation and application. Automation in Construction, 96(September), 103$127 . \quad$ Retrieved https://doi.org/10.1016/j.autcon.2018.08.017

Louis, J., \& Dunston, P. S. (2018). Integrating loT into operationa work fl ows for real-time and automated decision-making in repetitive construction operations. Automation in Construction,
94(April), $\quad 317-327 . \quad$ Retrieved

from

https://doi.org/10.1016/j.autcon.2018.07.005

Love, P. E. D., Matthews, J., \& Gates, B. (2019). The 'how' of benefits management for digital technology: From engineering to asset management. Automation in Construction, 107(July). Retrieved from https://doi.org/10.1016/j.autcon.2019.102930

Ma, Z., \& Ren, Y. (2017). Integrated Application of BIM and GIS: An Overview. Procedia Engineering, 196(June), 1072-1079. Retrieved from https://doi.org/10.1016/j.proeng.2017.08.064

Madakan, S., Ramaswamy, S., \& Tripathi, S. (2015). Internet of Things (IoT): A Literature Review. Journal of Computer and Communications, 3, 164-173. Retrieved 1 May 2019 from https://doi.org/10.4236/jcc.2015.35021

Magruk, A. (2015). The most important aspects of uncertainty in the Internet of Things field - context of smart buildings. Procedia Engineering, 122, 220-227. Retrieved from https://doi.org/10.1016/j.proeng.2015.10.028

Marsal-Llacuna, M.-L. (2018). Future living framework: Is blockchain the next enabling network? Technologica Forecasting \& Social Change, 128, 226-234. Retrieved from https://doi.org/10.1016/j.techfore.2017.12.005

Mcglinn, K., Wagner, A., Pauwels, P., Bonsma, P., Kelly, P., \& Sullivan, D. O. (2019). Interlinking geospatial and building geometry with existing and developing standards on the web. Automation in Construction, 103, 235-250. Retrieved from https://doi.org/10.1016/j.autcon.2018.12.026

Motamedi, A., Soltani, M. M., Setayeshgar, S., \& Hammad, A (2016). Extending IFC to incorporate information of RFID tags attached to building elements. Advanced Engineering Informatics, 30(1), 39-53. Retrieved from https://doi.org/10.1016/j.aei.2015.11.004

Nawari, N. O., \& Ravindran, S. (2019). Blockchain and the built environment: Potentials and limitations. Journal of Building Engineering Journal, 25(June). Retrieved from https://doi.org/10.1016/j.jobe.2019.100832

Novais, L., Manuel, J., \& Ortiz-bas, Á. (2019). A systematic literature review of cloud computing use in supply chain integration. Computers \& Industrial Engineering, 129, 296314. Retrieved from https://doi.org/10.1016/j.cie.2019.01.056

Pärn, E. A., \& Edwards, D. J. (2017). Conceptualising the FinDD API plug-in: A study of BIM-FM integration. Automation in Construction. Retrieved https://doi.org/10.1016/j.autcon.2017.03.015

Pauwels, P., Zhang, S., \& Lee, Y. (2017). Semantic web technologies in AEC industry: A literature overview. Automation in Construction, 73, 145-165. Retrieved from https://doi.org/10.1016/j.autcon.2016.10.003

Peng, Y., Li, S., \& Hu, Z. (2019). A self-learning dynamic path planning method for evacuation in large public buildings based on neural networks. Neurocomputing, 365, 71-85. Retrieved from https://doi.org/10.1016/j.neucom.2019.06.099

Petersen, K., Feldt, R., Mujtaba, S., \& Mattsson, M. (2008). Systematic Mapping Studies in Software Engineering. In 12th International Conference on Evaluation and Assessment in Software Engineering (Vol. 17). Swindon: UK: BCS Learning \& Development Ltd. Retrieved from https://doi.org/10.1016/j.pedneo.2016.08.011

Pezeshki, Z., Soleimani, A., \& Darabi, A. (2019). Application of BEM and using BIM database for BEM: A review. Journal of Building Engineering, 23, 1-17. Retrieved from https://doi.org/10.1016/j.jobe.2019.01.021

Pishdad-Bozorgi, P. (2017). Future Smart Facilities: State-of-theArt BIM-Enabled Facility Management. Journal of Construction Engineering and Management, 143(9), 02517006. Retrieved from https://doi.org/10.1061/(ASCE)CO.1943-7862.0001376

Plageras, A. P., Psannis, K. E., Stergiou, C., Wang, H., \& Gupta, B. B. (2018). Efficient loT-based sensor BIG Data collection - 
processing and analysis in smart buildings. Future Generation Computer Systems, 82, 349-357. Retrieved from https://doi.org/10.1016/j.future.2017.09.082

Ramprasad, B., Mcarthur, J., Fokaefs, M., Barna, C., Damm, M., \& Litoiu, M. (2018). Leveraging existing sensor networks as IoT devices for smart buildings. In IEEE World Forum on Internet of Things, WF-loT 2018 - Proceedings (Vol. January, pp. 452-457). IEEE. Retrieved from https://doi.org/10.1109/WF-loT.2018.8355121

Rashid, K. M., Louis, J., \& Fiawoyife, K. K. (2019). Wireless electric appliance control for smart buildings using indoor location tracking and BIM-based virtual environments. Automation in Construction, 101, 48-58. Retrieved from https://doi.org/10.1016/j.autcon.2019.01.005

Rice, J., \& Martin, N. (2018). Smart infrastructure technologies: Crowdsourcing future development and benefits for Australian communities. Technological Forecasting \& Social Change, (March), 119256. Retrieved from https://doi.org/10.1016/j.techfore.2018.03.027

Rubio, A., Board, C., Santofimia, M. J., Felix, J., Cantarero, R., Rubio, A., \& Felix, J. (2018). A common-sense based system for Geo-loT. Procedia Computer Science, 126, 665-674. Retrieved from https://doi.org/10.1016/j.procs.2018.07.301

Succar, B., \& Kassem, M. (2015). Macro-BIM adoption: Conceptual structures. Automation in Construction, 57, 64-79. Retrieved from https://doi.org/10.1016/j.autcon.2015.04.018

Tang, S., Shelden, D. R., Eastman, C. M., Pishdad-bozorgi, P., \& Gao, X. (2019). A review of building information modeling (BIM) and the internet of things (IoT) devices integration: Present status and future trends. Automation in Construction, 101(February), 127-139. Retrieved from https://doi.org/10.1016/j.autcon.2019.01.020

Terroso-saenz, F., González-vidal, A., Ramallo-gonzález, A. P., \& Skarmeta, A. F. (2019). An open loT platform for the management and analysis of energy data. Future Generation Computer Systems, 92, 1066-1079. Retrieved from https://doi.org/10.1016/j.future.2017.08.046

The British Standard Institution (BSI). PAS 180 - Smart citiesVocabulary (2014). Retrieved 1 May 2019 from http://shop.bsigroup.com/upload/PASs/Free-

Download/PAS180.pdf

Vandecasteele, F., Merci, B., \& Verstockt, S. (2017). Fireground location understanding by semantic linking of visual objects and building information models. Fire Safety Journal. Retrieved from https://doi.org/10.1016/j.firesaf.2017.03.083

Wang, H., Pan, Y., \& Luo, X. (2019). Integration of BIM and GIS in sustainable built environment: $A$ review and bibliometric analysis. Automation in Construction, 103, 41-52. Retrieved from https://doi.org/10.1016/j.autcon.2019.03.005

Wong, J. K. W., Ge, J., \& He, S. X. (2018). Digitisation in facilities management: A literature review and future research directions. Automation in Construction, 92, 312-326. Retrieved from https://doi.org/10.1016/j.autcon.2018.04.006

Woodhead, R., Stephenson, P., \& Morrey, D. (2018). Digital construction: From point solutions to loT ecosystem. Automation in Construction, 93(March), 35-46. Retrieved from https://doi.org/10.1016/j.autcon.2018.05.004

Xu, G., Li, M., Chen, C., \& Wei, Y. (2018). Cloud asset-enabled integrated loT platform for lean prefabricated construction. Automation in Construction, 93(September 2017), 123-134. Retrieved from https://doi.org/10.1016/j.autcon.2018.05.012

Xu, Q., Chong, H., \& Liao, P. (2019). Collaborative information integration for construction safety monitoring. Automation in Construction, 102, 120-134. Retrieved from https://doi.org/10.1016/j.autcon.2019.02.004

Yamamura, S., Fan, L., \& Suzuki, Y. (2017). Assessment of urban energy performance through integration of BIM and GIS for smart city planning. Procedia Engineering, 180, 1462-1472. Retrieved from https://doi.org/10.1016/j.proeng.2017.04.309
Yan, W., \& Sakairi, T. (2019). Geo CPS: Spatial challenges and opportunities for CPS in the geographic dimension. Journal of Urban Management, 8(3), 331-341. Retrieved from https://doi.org/10.1016/j.jum.2019.09.005

Yang, Y., Ng, S. T., Xu, F. J., \& Skitmore, M. (2018). Towards sustainable and resilient high density cities through better integration of infrastructure networks. Sustainable Cities and Society, 42(April), 407-422. Retrieved from https://doi.org/10.1016/j.scs.2018.07.013

Ye, Z., Yin, M., Tang, L., \& Jiang, H. (2018). Cup-of-Water Theory: A Review on the Interaction of BIM, IoT and Blockchain During the Whole Building Lifecycle. In Proceedings of the 35th International Symposium on Automation and Robotics in Construction (ISARC). Retrieved from https://doi.org/10.22260/isarc2018/0066

Yin, X., Liu, H., Chen, Y., \& Al-hussein, M. (2019). Building information modelling for off-site construction: Review and future directions. Automation in Construction, 101, 72-91. Retrieved from https://doi.org/10.1016/j.autcon.2019.01.010

Zachary, S., Binder, B., Matsui, K., Lancaster, Z. S., Binder, R. B., Matsui, K., ... Corre, O. Le. (2019). Developing a theory of an object-oriented city: Building energy for urban problems. Energy Procedia, 158, 4210-4217. Retrieved from https://doi.org/10.1016/j.egypro.2019.01.807

Zhai, Y., Chen, K., Zhou, J. X., Cao, J., Lyu, Z., Jin, X., ... Huang, G. Q. (2019). An Internet of Things-enabled BIM platform for modular integrated construction: A case study in Hong Kong. Advanced Engineering Informatics, 42(October), 100997. Retrieved from https://doi.org/10.1016/j.aei.2019.100997

Zhengdao, C., Hong, J., Xue, F., Qiping, G., Xu, X., \& Kayan, M. (2016). Schedule risks in prefabrication housing production in Hong Kong: a social network analysis. Journal of Cleaner Production, 134, 482-494. Retrieved from https://doi.org/10.1016/j.jclepro.2016.02.123

Zhengdao, C., Hong, J., Xue, F., Qiping, G., Xu, X., \& Luo, L. (2016). SWOT analysis and Internet of Things-enabled platform for prefabrication housing production in Hong Kong. Habitat International, 57, 74-87. Retrieved from https://doi.org/10.1016/j.habitatint.2016.07.002

Zhengdao, C., Xue, F., Li, X., \& Hong, J. (2018). An Internet of Things-enabled BIM platform for on-site assembly services in prefabricated construction. Automation in Construction, 89(July 2017), 146-161. Retrieved from https://doi.org/10.1016/j.autcon.2018.01.001

Zhengdao, C., Zhong, R. Y., Xue, F., Xu, G., Chen, K., Guoquan, G., \& Qiping, G. (2017). Integrating RFID and BIM technologies for mitigating risks and improving schedule performance of prefabricated house construction. Journal of Cleaner Production, 165, 1048-1062. Retrieved from https://doi.org/10.1016/j.jclepro.2017.07.156

Zhong, R. Y., Peng, Y, Fang, J., Xu, G., Xue, F., Zou, W., \& Huang, G. Q. (2015). Towards Physical Internet-enabled Prefabricated Housing Construction in Hong Kong. IFACPapersOnLine, 48(3), 1079-1086. Retrieved from https://doi.org/10.1016/j.ifacol.2015.06.227

Zhong, R. Y., Peng, Y., Xue, F., Fang, J., Zou, W., Luo, H., .. Huang, G. Q. (2017). Prefabricated construction enabled by the Internet-of-Things. Automation in Construction, 76, 59-70. Retrieved from https://doi.org/10.1016/j.autcon.2017.01.006

Zhong, R. Y., Xu, X., \& Wang, L. (2017). IoT-enabled Smart Factory Visibility and Traceability using Laser- scanners. Procedia Manufacturing, 10, 1-14. Retrieved from https://doi.org/10.1016/j.promfg.2017.07.103

Zhou, C., Luo, H., Fang, W., Wei, R., \& Ding, L. (2019). Cyberphysical-system-based safety monitoring for blind hoisting with the internet of things: A case study. Automation in Construction, 97(April 2018), 138-150. Retrieved from https://doi.org/10.1016/j.autcon.2018.10.017 